\title{
Motivasi Kader Meningkatkan Keberhasilan Kegiatan Posyandu
}

\author{
Henni Djuhaeni, ${ }^{1}$ Sharon Gondodiputro, ${ }^{1}$ Rossi Suparman ${ }^{2}$ \\ ${ }^{1}$ Pascasarjana Ilmu Kesehatan Masyarakat Fakultas Kedokteran Universitas Padjadjaran \\ ${ }^{2}$ Rumah Sakit Umum Daerah 45 Kuningan/Bandarosa, Jawa Barat
}

\begin{abstract}
Abstrak
Salah satu komponen sistem kesehatan di Indonesia adalah pemberdayaan masyarakat, khususnya posyandu yang keberhasilan kegiatannya bergantung pada peran serta kader dan masyarakat. Peran serta kader dan masyarakat sangat dipengaruhi oleh faktor motivasi yang mereka miliki. Penelitian ini bertujuan untuk menganalisis pengaruh serta faktor motivasi yang paling berpengaruh terhadap peran serta kader dan masyarakat dalam kegiatan posyandu di Kabupaten Kuningan selama tahun 2009. Metode penelitian cross sectional explanatory survey dengan menggunakan kuesioner. Total sampel sebanyak 300 responden, terdiri dari masing-masing 100 orang untuk kader aktif dan tidak aktif yang diambil secara multistage sampling serta 100 orang masyarakat sebagai kontrol diambil secara purposive sampling. Motivasi internal dan eksternal sebagai variabel independen dan partisipasi kader/masyarakat sebagai variabel dependen, kemudian dianalisis menggunakan teknik structural equation modeling (SEM). Hasil penelitian memperlihatkan bahwa faktor motivasi berpengaruh terhadap peran serta kader dan masyarakat dalam posyandu. Meskipun demikian terdapat berbagai variasi pengaruh, pada kader aktif motivasi eksternal lebih berpengaruh $(\mathrm{p}=0,97)$ dibandingkan dengan motivasi internal $(\mathrm{p}=-0,41)$. Pada kader tidak aktif terjadi hal sebaliknya, sedangkan pada masyarakat, kedua faktor motivasi menunjukkan pengaruh yang tidak bermakna. Simpulan, pengaruh dan perbedaan pengaruh motivasi terhadap peran serta kader dan masyarakat menentukan keberhasilan kegiatan posyandu. [MKB. 2010;42(4):140-8].
\end{abstract}

Kata kunci: Faktor motivasi, kader, masyarakat, peran serta, posyandu

\section{Cadres Motivation as the Drive for the Success of Posyandu}

\begin{abstract}
One of the most important component of the health system in Indonesia is community empowerment, especially posyandu, which depends on their cadres and the community. It was hypothetically assumed that motivation will increase the participation for both cadres and community in the posyandu. The study aims were to analyze the effect of motivation and also determine which motivation factors that had the most influence towards participation in Kuningan district during 2009. The method adapted cross sectional explanatory survey using questionnaire. A total of 300 respondents were carried out, consisting 100 respondents each taken from active and inactive cadres (multistage sampling) and other 100 taken from the community (purposive sampling). Independent variables (internal and external motivation) and dependent variables (community participation) were mentioned and analyzed using structural equation modeling (SEM) technique. The results showed that motivation were actually had influence towards participations for both cadres and community in posyandu. However, the effect varies between groups. On active cadres, external motivation had more influence $(\mathrm{p}=0.97)$ compared to internal motivation $(\mathrm{p}=$ -0.41). The exact opposite happened in inactive cadres (internal more than external) and community. It can be concluded that cadres motivation is important as the drive for the success of posyandu. [MKB. 2010;42(4):140-8].
\end{abstract}

Key words: Cadres, community empowerment, motivation, participation, posyandu 


\section{Pendahuluan}

Mengaktifkan pemberdayaan dan peran serta masyarakat merupakan salah satu subsistem dari sistem kesehatan nasional (SKN) yang sangat penting dalam menentukan keberhasilan, kemandirian, serta kesinambungan pembangunan kesehatan dan merupakan kebijakan pemerintah. Kebijakan ini juga dilaksanakan oleh pemerintah daerah Provinsi Jawa Barat dalam bentuk upaya kesehatan bersumber daya masyarakat (UKBM) yang salah satu contohnya adalah posyandu. Posyandu merupakan ujung tombak pelayanan kesehatan yang bersumber dari, oleh, dan untuk masyarakat, menunjang permasalahan kesehatan ibu dan anak khususnya, serta masalah kualitas hidup masyarakat seperti gizi buruk anak balita, kekurangan gizi, busung lapar, dan masalah kesehatan lainnya. $^{3}$

Saat ini berbagai permasalahan timbul dalam pelaksanaan posyandu antara lain: (1) hanya sekitar $40 \%$ jumlah posyandu dapat menjalankan fungsinya dengan baik, (2) peralatan tidak memadai, (3) tidak memiliki tempat pelayanan yang layak, (4) pembinaan terhadap posyandu belum merata, (5) cakupan posyandu masih rendah $(<50 \%)$ dan sebagian besar adalah anak di bawah usia 2 tahun, (6) hampir 100\% ibu pernah mendengar posyandu, tetapi yang hadir pada saat kegiatan posyandu kurang dari separuhnya, serta (7) belum memiliki jumlah kader yang cukup bila dibandingkan dengan sasaran, atau walaupun jumlahnya mencukupi tetapi kadernya tidak aktif. ${ }^{4}$ Di pihak lain keterbatasan sumber daya manusia di puskesmas dibandingkan dengan jumlah penduduk yang dilayaninya menyebabkan peran kader menjadi sangat penting dalam berbagai upaya/kegiatan kesehatan, khususnya di posyandu.

Keberhasilan dan kesinambungan kegiatan posyandu sangat bergantung pada kader serta masyarakat yang datang untuk berperan serta. Jumlah kader yang kurang bila dibandingkan dengan sasaran, kader tidak aktif, dan kader drop out yang merupakan masalah krusial dalam pelaksanaan posyandu. ${ }^{3}$ Permasalahan yang sama dialami oleh posyandu di kabupaten Kuningan, yaitu salah satu kabupaten yang mempunyai rasio posyandu/desa terendah di Jawa Barat sebanyak 3,51 atau 3 sampai 4 posyandu/desa/kecamatan. Jumlah posyandu masih jauh dari target yang diharapkan, yaitu 1.761 posyandu untuk 176.142 balita yang ada di kabupaten Kuningan (tahun 2006) dan dari tahun ke tahun jumlahnya makin menurun dari 1.346 pada tahun 2001 menjadi 1.315 posyandu pada tahun 2007. ${ }^{5}$ Selain jumlah posyandu, kader merupakan kunci utama dalam kegiatan posyandu mulai dari perencanaan, pelaksanaan termasuk pencatatan, dan pelaporan. Peran aktif kader di sini sangat menentukan kelangsungan dan perkembangan posyandu, di pihak lain jumlah kader tidak aktif, yaitu kader yang terdaftar tetapi tidak melaksanakan dan tidak terlibat dalam kegiatan posyandu semakin banyak. ${ }^{6}$

Data Dinas Kesehatan kabupaten Kuningan tahun 2007 menunjukkan bahwa pencapaian jumlah kader hanya $76 \%$ dan kader yang aktif hanya $80 \%$. Walaupun rasio kader lebih tinggi dari angka Nasional $(69,2 \%)$, tetapi 3 tahun terakhir mengalami penurunan rata-rata $2,7 \%$ untuk tiap posyandu. Dampaknya antara lain cakupan $\mathrm{D} / \mathrm{S}$, yaitu jumlah balita yang datang dan ditimbang dibandingkan dengan jumlah semua balita, juga mengalami penurunan, dari $78,03 \%$ (tahun 2006) menjadi 69,0\% (tahun 2007).

Banyak sekali faktor yang mempengaruhi kondisi kader dan masyarakat untuk terlibat dalam seluruh kegiatan posyandu, antara lain pengetahuan kader, informasi kegiatan posyandu, motivasi kader, dll. Motivasi merupakan faktor paling dominan, baik yang berasal dari dalam diri mereka sendiri ataupun yang berasal dari luar/lingkungannya. Penelitian di Kecamatan Pasawahan kabupaten Kuningan terhadap 30 orang kader dari 10 desa memperlihatkan jumlah kader aktif hanya $39,7 \%$, sebagian besar $(55 \%)$ disebabkan motivasi yang rendah karena merasa terganggu aktivitas kerjanya oleh kegiatan posyandu. Di pihak lain, sebanyak $60 \%$ kader aktif termotivasi aktif dalam posyandu karena merasa mendapatkan manfaat serta insentif dari kegiatan posyandu. ${ }^{4}$

Adakah pengaruh faktor motivasi, faktor motivasi apa yang paling berpengaruh serta bagaimana perbedaan pengaruhnya terhadap peran serta kader dan masyarakat dalam kegiatan posyandu di Kabupaten Kuningan sama sekali belum diketahui. Penelitian ini bertujuan untuk menganalisis pengaruh dan faktor motivasi yang paling berpengaruh terhadap peran serta kader dan masyarakat dalam kegiatan posyandu di kabupaten Kuningan. Dengan diketahuinya faktor motivasi yang paling berperan, dapat dilakukan 
intervensi yang lebih tepat dan terarah dalam meningkatkan aktivitas kader sehingga memiliki daya ungkit yang besar terhadap pencapaian program pembangunan kesehatan di kabupaten Kuningan.

\section{Metode}

Penelitian ini dilaksanakan di posyandu dusun kabupaten Kuningan tahun 2009. Rancangan penelitian adalah cross sectional explanatory survey ${ }^{7}$ dengan menggunakan kuesioner yang telah diuji validitas dan realibilitasnya terhadap para kader posyandu aktif (mengikuti $\geq 80 \%$ kegiatan) dan tidak aktif $(<80 \%$ kegiatan) selama setahun terakhir. Populasi adalah semua kader terdaftar di posyandu kabupaten Kuningan sebanyak 6.768 orang, terdiri dari 5.527 kader aktif dan 1.241 kader tidak aktif. Besaran sampel penelitian dihitung menggunakan pendekatan Steiger's root means square error approximation (RMSEA) dengan menggunakan software statistica $6 .^{8}$ Diperoleh 300 responden, masingmasing 100 orang kader aktif dan tidak aktif yang diambil secara multistage sampling serta 100 orang masyarakat (tetangga yang sebelumnya pernah mengikuti kegiatan posyandu) diambil secara purposive sampling yang dipergunakan sebagai kontrol.

Variabel independen terdiri dari: (1) motivasi internal yang dibentuk oleh empat indikator atau kontributor, yaitu kebutuhan akan penghargaan, aktualisasi diri, prestasi, serta tanggung jawab (keterlibatan dalam posyandu secara sukarela/ tidak terdapat paksaan dari pihak manapun); (2) motivasi eksternal dibentuk oleh tiga indikator, yaitu hubungan sosial, kondisi lingkungan, dan insentif. Variabel dependen adalah peran serta dengan kontributor berupa sumbangan tenaga, dana, materi, serta pemikiran/ide/gagasan strategi yang berhubungan dengan kesuksesan kegiatan posyandu tersebut.

Pengujian hipotesis menggunakan metode structural equation modeling (SEM) dengan program statistik LISREL 8 berdasarkan pada beberapa pertimbangan, antara lain teknik ini memungkinkan pengujian hubungan antar variabel secara serentak dalam satu waktu. Selain itu, baik variabel independen maupun dependen merupakan variabel laten karena unobserved variables. ${ }^{8}$

\section{Hasil}

Hasil penelitian menunjukkan bahwa ketiga kelompok responden mempunyai karakteristik usia produktif, sebagian besar $(89,8-97,7 \%)$ telah menikah, proporsi pendidikan terbanyak $(36,4 \%)$ adalah sekolah menengah atas (SMA) kecuali untuk kader tidak aktif 40,9\% lulusan sekolah dasar (SD). Pada kader aktif mayoritas pekerjaan ibu rumah tangga (89,8\%). Pada ketiga kelompok responden sebagian besar $(72,7 \%)$ tidak memiliki suami yang sedang memegang jabatan tertentu dalam lingkungan masyarakatnya. Berdasarkan lamanya menjadi kader, sudah ada kader aktif

Tabel 1 Perbedaan Nilai Kecocokan (Goodness and Fit Index) Model Pengaruh Faktor Motivasi terhadap Peran Serta antara Kader Aktif, Kader Tidak Aktif, dan Masyarakat dalam Kegiatan Posyandu

\begin{tabular}{|c|c|c|c|}
\hline \multirow{3}{*}{ Kriteria } & \multicolumn{3}{|c|}{ Nilai } \\
\hline & \multicolumn{2}{|c|}{ Kader } & \multirow{2}{*}{ Masyaraka } \\
\hline & Aktif & Tidak Aktif & \\
\hline Chi-square & 35,44 & 45,15 & 41,13 \\
\hline Degree of freedom & 31 & 38 & 36 \\
\hline Nilai $p$ & 0,27 & 0,20 & 0,26 \\
\hline GFI & 0,94 & 0,92 & 0,93 \\
\hline AGFI & 0,87 & 0,87 & 0,87 \\
\hline RMR & 0,06 & 0,06 & 0,08 \\
\hline RMSEA & 0,04 & 0,04 & 0,04 \\
\hline Goodness and fit & \multicolumn{3}{|c|}{ Fit $^{*}$} \\
\hline
\end{tabular}




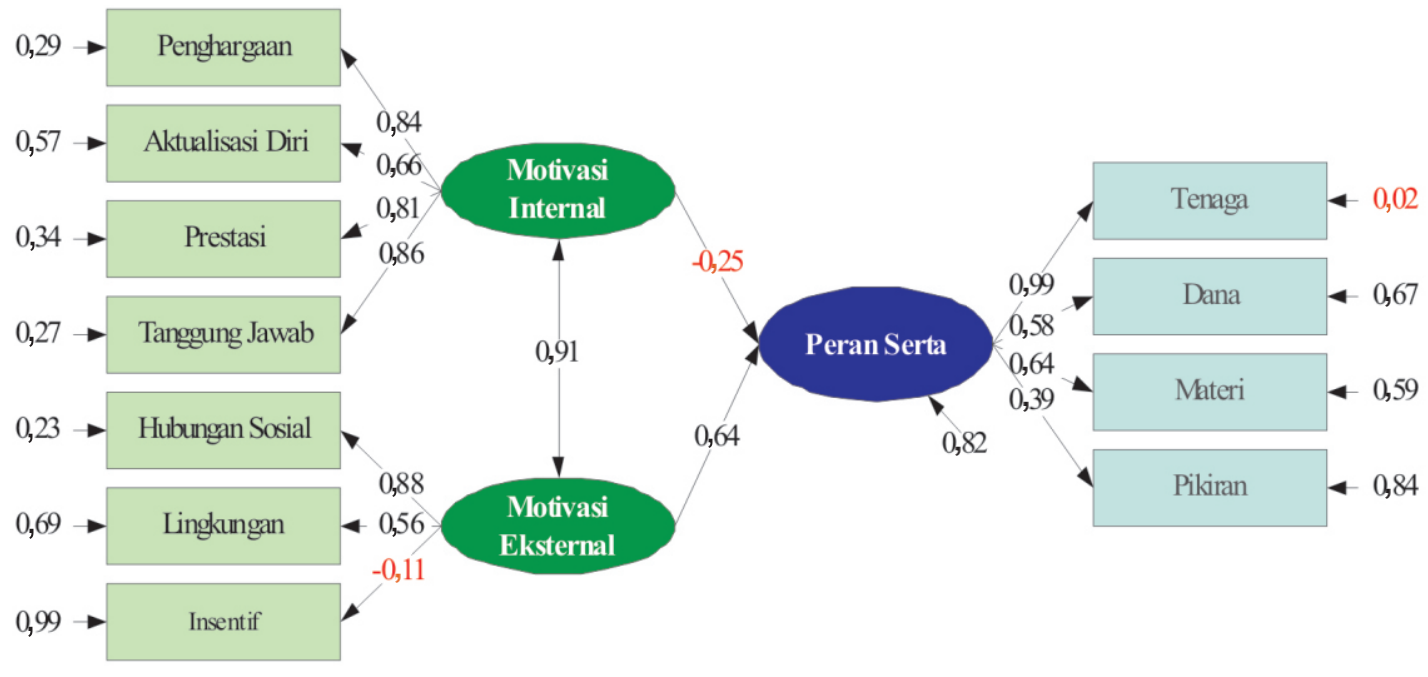

Chi-Square $=35,68 ; \mathrm{df}=27$; $\mathrm{p}$-value $=0,12 ; \mathrm{RMSEA}=0,03 ; \mathrm{RMR}=0,04 ; \mathrm{GFH}=0,98 ; \mathrm{AGFI}=0,95$

\section{Gambar 1 Model Faktor Motivasi pada Peran Serta dalam Kegiatan Posyandu}

yang terlibat dalam kegiatan posyandu selama 35 tahun, sedangkan untuk kader tidak aktif hanya 23 tahun.

Pengujian model pengaruh faktor motivasi terhadap peran serta dalam kegiatan posyandu pada ketiga kelompok semuanya fit, yaitu tidak ada perbedaan model penelitian dengan model teoritik, artinya model didukung oleh data empirik dan dapat digunakan untuk pengujian variabel maupun kontributor pembentuknya seperti tampak pada Tabel 1 .

Faktor motivasi berpengaruh terhadap peran serta semua responden, pengaruh eksternal lebih bermakna $(\mathrm{p}=0,64)$ dibandingkan dengan internal $(p=-0,25)$ serta ada hubungan yang sangat erat antara kedua motivasi $(\mathrm{p}=0,91)$. Tampak pula bahwa penghargaan, aktualisasi diri, prestasi, serta tanggung jawab mempunyai kontribusi positif dan bermakna dalam membentuk motivasi internal. Demikian juga hubungan sosial dan lingkungan dapat membentuk motivasi eksternal kecuali insentif. Tenaga merupakan kontributor terbesar $(p=0,99)$ selain dana, materi, dan pikiran terhadap peran serta kader dalam posyandu (Gambar 1).

Hasil pengujian secara terpisah untuk ketiga

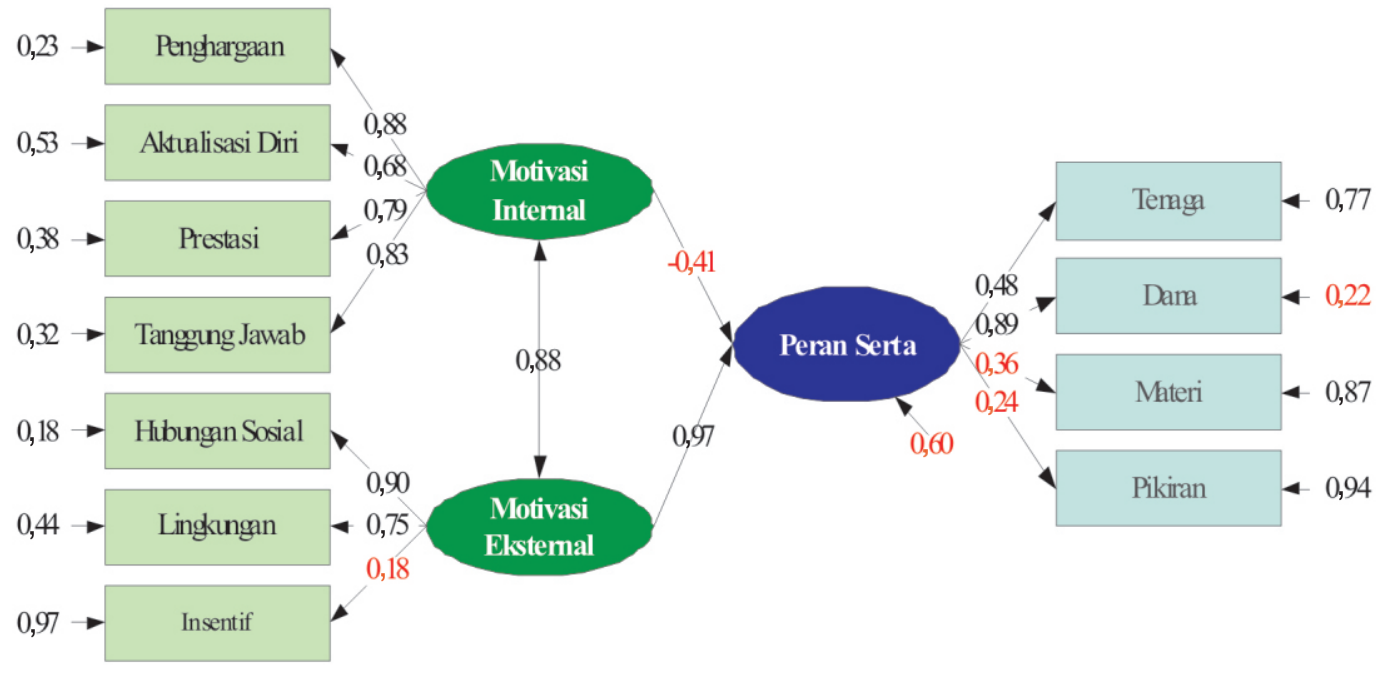

Chi-Square $=35,44 ; \mathrm{df}=31 ; \mathrm{p}$-value $=0,27$; RMSEA $=0,04 ; \mathrm{RMR}=0,06 ; \mathrm{GFI}=0,94 ; \mathrm{AGF}=0,87$

Gambar 2 Model Faktor Motivasi pada Peran Serta Kader Aktif dalam Kegiatan Posyandu 


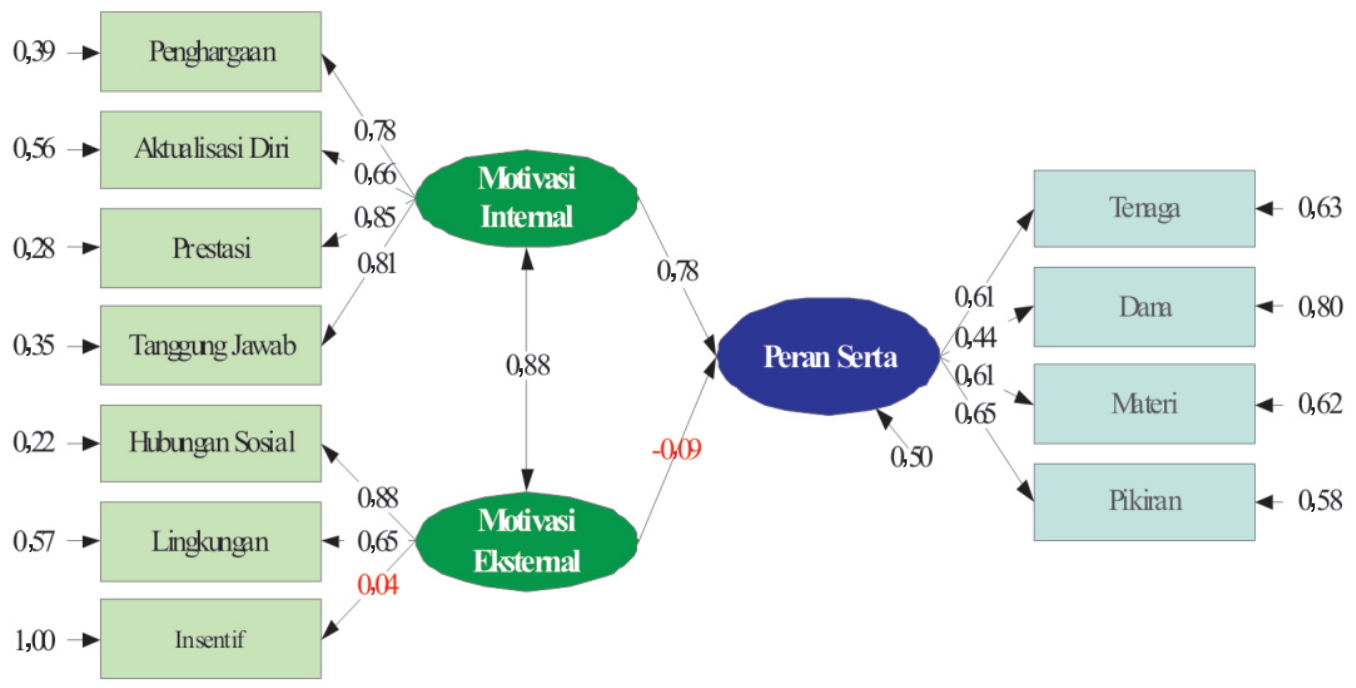

Chi-Square $=45,15 ; \mathrm{df}=38$; $\mathrm{p}$-value $=0,20$; RMSEA=0,04; RMR=0,06; GFI 0,$92 ; \mathrm{AGF} 0,87$

\section{Gambar 3 Model Faktor Motivasi pada Peran Serta Kader Tidak Aktif Dalam Kegiatan Posyandu}

kelompok responden tidak terlalu berbeda dalam hal kontribusi motivasi internal maupun ekternal, tetapi memperlihatkan kontributor yang sangat berbeda untuk peran serta tenaga, dana, materi, dan pikiran, sedangkan masyarakat tidak dapat menggambarkan peran serta dalam posyandu (Gambar 2, 3, dan 4).

Gambar 2, 3, dan 4 juga memperlihatkan perbedaan pengaruh faktor motivasi terhadap peran serta antara kader aktif, kader tidak aktif, dan masyarakat dengan besaran pengaruh, terlihat pada Tabel 2.

\section{Pembahasan}

Berdasarkan pada karakteristik responden, hasil penelitian menunjukkan kesesuaian baik dengan teori maupun hasil penelitian sebelumnya. Semakin bertambah usia seseorang, semakin

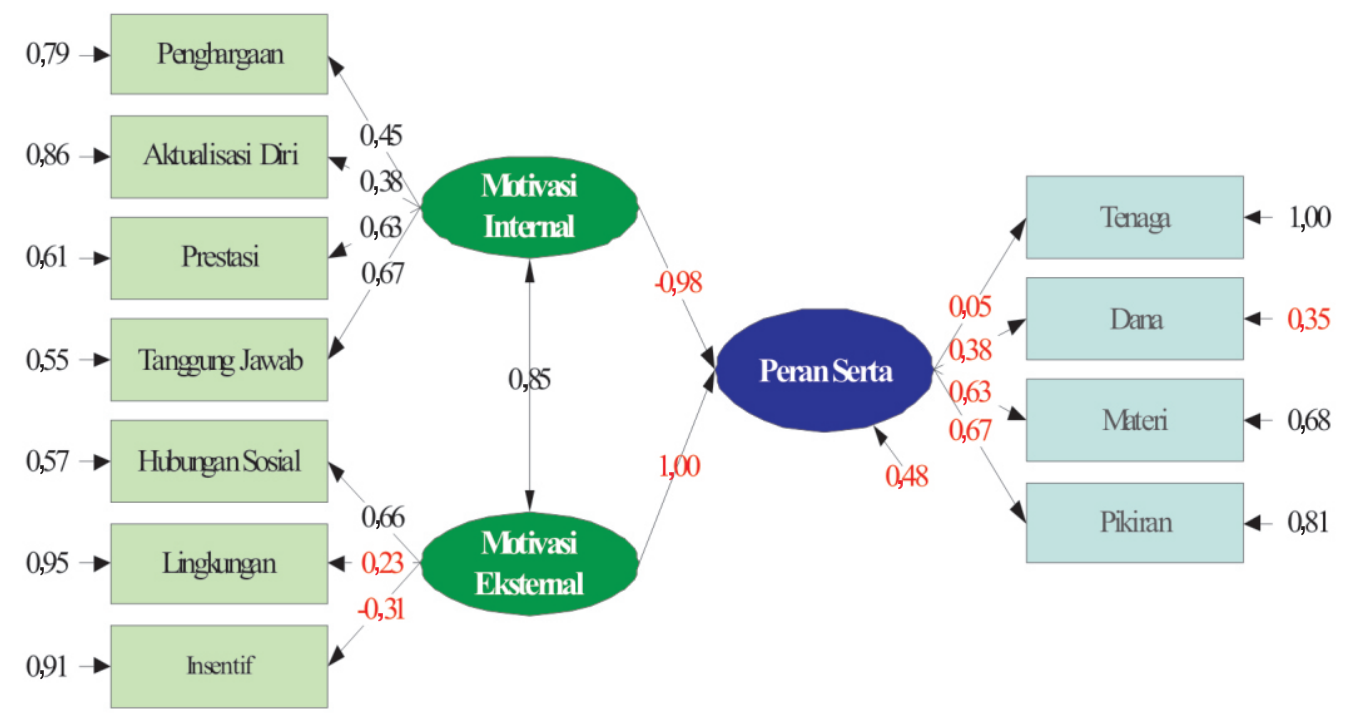

Chi-Square=41,13; df=36; p-value=0,26; RMSEA=0,04; RMR=0,08; GF=0,93; AGF=0,87

Gambar 4 Model Faktor Motivasi pada Peran Serta Masyarakat dalam Kegiatan Posyandu 
Tabel 2 Perbedaan Nilai Koefisien Pengaruh Faktor Motivasi pada Peran Serta antara Kader Aktif, Tidak Aktif, dan Masyarakat

\begin{tabular}{lccc}
\hline \multirow{2}{*}{ Faktor } & \multicolumn{2}{c}{ Kader } & \multirow{2}{*}{ Masyarakat } \\
\cline { 2 - 4 } & Aktif & Tidak Aktif & $-0,98$ \\
Motivasi Internal & $-0,41$ & 0,78 & $-1,00$ \\
Motivasi Eksternal & 0,97 & $-0,09$ & 0,85 \\
Korelasi antar faktor motivasi & 0,88 & 0,88 & \\
\hline
\end{tabular}

bertambah kedewasaan dan banyak menyerap informasi yang mempengaruhinya. Responden terbanyak berusia produktif merupakan potensi memberikan pengaruh dan dapat menjadi sumber informasi supaya terlibat dalam semua kegiatan posyandu. ${ }^{9}$ Persentase terbesar responden telah menikah, pernikahan memaksa peningkatan tanggung jawab terhadap suatu pekerjaan menjadi lebih berharga dan penting. Hal ini sesuai dengan hasil penelitian bahwa tanggung jawab memiliki pengaruh paling besar terhadap peran serta kader dan masyarakat dalam kegiatan posyandu. ${ }^{10}$ Pendidikan merupakan faktor predisposisi seseorang untuk bertindak atau berperilaku, karena pendidikan merupakan hal yang mendasar untuk seseorang berperilaku ${ }^{11}$ termasuk perilaku peran serta dalam kegiatan posyandu. Sebagian besar pendidikan responden adalah SMA sehingga mampu membantu untuk menggerakkan masyarakat dalam kegiatan posyandu, sedangkan responden berpendidikan SD, dibutuhkan untuk melaksanakan kegiatan posyandu karena mereka dapat membaca dan menulis. Mayoritas pekerjaan adalah ibu rumah tangga yang relatif memiliki waktu senggang dibandingkan dengan ibu bekerja untuk terlibat dalam kegiatan posyandu. Sebagian besar $(72,7 \%)$ responden tidak memiliki suami yang sedang memegang jabatan tertentu dalam lingkungan masyarakatnya, artinya keterlibatan sebagai kader bukan dikarenakan jabatan suami, melainkan karena motivasi kesadaran dirinya sendiri. Keadaan ini merupakan potensi positif karena akan bersifat langgeng terbukti dari loyalitas kader yang sudah terlibat dalam kurun waktu yang lama bahkan mencapai 35 tahun.

Hasil pengujian secara bersama-sama ataupun terpisah untuk ketiga kelompok responden memperlihatkan hasil yang tidak terlalu berbeda dalam hal kontributor motivasi internal maupun ekternal. Motivasi internal dalam penelitian ini dapat digambarkan oleh semua indikator pembentuknya (penghargaan, aktualisasi diri, prestasi, dan tanggungjawab). Tanggung jawab merupakan kontributor terbesar motivasi internal, hal ini sesuai dengan "Motivation New Directions for Theory" bahwa motivasi mewakili proses psikologik yang akan menyebabkan timbulnya tanggung jawab dan merupakan tahap awal kemauan bertindak untuk mencapai tujuan. Tanggung jawab merupakan kewajiban untuk melaksanakan fungsi (pekerjaan dan kepercayaan terhadap potensi yang dimiliki) dengan sebaikbaiknya. Setiap orang ingin dipercaya, diikutsertakan, dan diakui sebagai orang berpotensi, sehingga timbul rasa percaya diri dan siap untuk memikul tanggung jawab lebih besar. Hal ini dapat terekspresikan dalam kegiatan sehari-hari terutama terhadap kegiatan sosial seperti kerja bakti, pembangunan sarana prasarana masyarakat, kegiatan peringatan hari besar, d1l. ${ }^{12}$

Hasil penelitian menunjukkan pengetahuan responden tentang posyandu cukup baik, hal ini merupakan potensi kesinambungan perannya sebagai kader sesuai penelitian Regers yang dikutip Suryana dan Sumantri, ${ }^{13}$ mengungkapkan sebelum seseorang mengadopsi perilaku baru, terjadi proses tertentu yang diawali dengan kesadaran terhadap stimulus di dalam dirinya. Proses penerimaan perilaku baru akan bersifat langgeng bila didasari pengetahuan, kesadaran, dan sikap positif.

Penghargaan adalah indikator selanjutnya yang memiliki kontribusi bermakna untuk faktor motivasi internal. Penghargaan yang diinginkan umumnya adalah rasa hormat dan status dalam berbagai bentuk antara lain pujian, pengakuan atas prestasi, dan pemberian simbol status (kekuasaan) termasuk juga memperoleh penghargaan dalam keterlibatannya di kegiatan posyandu. Program revitalisasi posyandu yang memberikan stimulus berupa kompetisi akan meningkatkan motivasi berprestasi kader dan masyarakat yang biasanya tidak mencari uang untuk kedudukan atau keamanan ekonomis, tetapi hanya menginginkan umpan balik tentang tugasnya.

Ada perbedaan hasil tentang penghargaan, 
kader aktif memperlihatkan motivasi untuk penghargaan paling dominan, sesuai dengan teori Maslow yang mengemukakan bahwa setiap manusia mempunyai kebutuhan rasa ingin dihargai. ${ }^{14}$ Pengakuan terhadap penghargaan merupakan alat motivasi yang cukup ampuh, bahkan dapat melebihi kepuasan pemberian kompensasi. Hal ini sesuai dengan teori $\mathrm{Mc}$ Clelland yang menyatakan bahwa orang dengan motivasi prestasi mempunyai prakarsa untuk menuju sukses dan memiliki tingkat "needs of achievement" (n-ach) yang tinggi serta tidak terpengaruh oleh imbalan uang. ${ }^{14}$ Seseorang dengan $\mathrm{n}$-ach yang tinggi biasa berpikir tentang mengerjakan sesuatu yang lebih baik berdasarkan pada kemampuan sendiri, bersedia menerima risiko yang relatif tinggi, umpan balik yang nyata tentang pelaksanaan tugasnya, serta keinginan mendapat tanggung jawab pemecahan masalah. ${ }^{15}$

Aktualisasi diri merupakan kontributor untuk motivasi internal yang paling tidak bermakna pada penelitian ini, sesuai teori Maslow bahwa aktualisasi diri merupakan motif intrinsik tertinggi dan sulit untuk dipenuhi oleh individu sebelum kebutuhan pada tingkatan yang lebih rendah di bawahnya agar terpenuhi. ${ }^{14}$ Dengan demikian dapat dikatakan bahwa motivasi kader dan masyarakat kabupaten Kuningan masih berada dalam tingkatan menengah ke bawah dalam mengapresiasikan potensi diri terhadap lingkungannya.

Hubungan sosial merupakan kontributor yang paling bermakna untuk motivasi eksternal, kecenderungan untuk memperoleh kepuasan dari hubungan sosial ini merupakan sifat manusia sesuai penelitian Morse dan Weiss seperti dikutip oleh Suryana dan Sumantri ${ }^{13}$ yang menyatakan seseorang akan terus bekerja, meskipun tidak mendapatkan pemberian bentuk ekonomis karena apabila mereka tidak bekerja, mereka merasa kehilangan banyak teman dalam pekerjaan.

Manusia sebagai makhluk sosial memiliki kecenderungan selalu membutuhkan orang lain untuk menjalin hubungan dan ingin hidup berkelompok agar mereka dapat lebih diterima oleh lingkungan sekitarnya. Hal ini makin menguatkan manfaat posyandu sebagai salah satu sarana untuk bertukar pendapat dan pengalaman serta bermusyawarah untuk memecahkan masalah yang dihadapi. Faktor eksternal inilah yang salah satunya membuat kader dan masyarakat merasa nyaman dalam kegiatan posyandu. Kondisi lingkungan yang nyaman, aman, tenang, dan didukung oleh peralatan yang memadai akan membuat orang senang untuk bekerja serta produktif. Sikap ini juga ditunjukkan oleh kader dan masyarakat yang senang berlama-lama dalam kegiatan posyandu dan mengisinya dengan saling berinteraksi membuat hubungan di antara kader dan masyarakat menjadi lebih dekat, rasa kekeluargaan makin terbentuk, serta produktivitas untuk kerja sosial yang lain pun menjadi lebih baik.

Insentif sebagai bagian dari faktor motivasi eksternal ternyata tidak begitu diharapkan oleh kader dan masyarakat, hal ini mengingat bahwa mereka tergerak bukan karena menginginkan uang dari posyandu, justru mereka mengeluarkan uang untuk terlibat dalam posyandu, misalnya pengeluaran untuk biaya transportasi, konsumsi, dan lain-lain. Keadaan ini sesuai dengan teori Hawtorn dan Herzberg bahwa bukan kebutuhan uang (gaji) atau insentif yang membuat orang menjadi produktif/mau berperan serta, seperti teori Frederick Taylor, melainkan perhatian dan faktor kepuasan. Kekurangan gaji dan faktor ketidakpuasan lainnya dapat menimbulkan ketidakpuasan bagi pekerja, tetapi juga tidak dapat membuatnya puas; hanya faktor kepuasan atau motivator yang dapat membuat pekerja puas serta meningkatkan motivasi mereka. ${ }^{14}$ Insentif tidak begitu bermakna karena kader dan masyarakat kabupaten Kuningan kurang agresif dalam mengungkapkan upah yang diinginkan secara jujur. Ada jiwa 'pemalu' yang dimiliki oleh tipikal suku Sunda dibandingkan dengan suku yang lain di Indonesia dan mereka menganggap tidak layak mengharapkan imbalan berbentuk uang/insentif dari posyandu. ${ }^{12}$

Penelitian ini menunjukkan pula korelasi signifikan $(0,91)$ antara faktor motivasi internal dan eksternal pada model keseluruhan baik kader aktif, kader tidak aktif maupun masyarakat, artinya saling melengkapi untuk terbentuknya motivasi seseorang terhadap peran sertanya dalam kegiatan posyandu di kabupaten Kuningan.

Tenaga merupakan bentuk kontributor paling bermakna pada model keseluruhan kader dan masyarakat. Mereka merasa kontribusi tenaga dalam segala bentuk khususnya secara fisik lebih banyak tersalurkan dalam pelaksanaan kegiatan posyandu, terutama kegiatan 5 meja yang rutin mereka lakukan, berupa pemeriksaan, pencatatan, penimbangan, pengisian kartu menuju sehat 
(KMS), dan konseling.

Ada perbedaan bentuk peran serta antara kader aktif dan tidak aktif, serta masyarakat. Kader aktif merasa lebih banyak berkontribusi dalam bentuk dana, hal ini dapat dipahami mengingat kader aktif merupakan ujung tombak sebelum, selama, dan setelah pelaksanaan kegiatan posyandu. Kader tidak aktif memberikan kontribusi berupa pemikiran yang lebih banyak tersalurkan dalam kegiatan posyandu seperti ide, gagasan, dan pendapat yang menumbuhkan rasa percaya diri karena pendapatnya dihargai orang lain. Hasil ke-3 kontributor peran serta kelompok masyarakat menunjukkan nilai yang semuanya tidak bermakna. Hal ini sesuai dengan kenyataan bahwa mereka tidak memberikan kontribusi terhadap kegiatan posyandu, tetapi mereka hanya membawa diri dan anak mereka untuk mengikuti kegiatan posyandu.

Terdapat perbedaan besarnya pengaruh motivasi pada ketiga kelompok; pada kader aktif, faktor motivasi eksternal berpengaruh lebih bermakna dibandingkan dengan internal terhadap peran serta dalam kegiatan posyandu. Hal ini sesuai dengan teori evaluasi kognitif Jordan bahwa pengaruh motivasi intrinsik/internal berkurang atau melemah apabila seorang telah termotivasi oleh dorongan ekstrinsik/eksternal yang lebih kuat. Kader dan masyarakat sebagai makhluk sosial berinteraksi dalam kegiatan posyandu tanpa melemahkan motivasi internal yang mereka miliki. Manusia merupakan makhluk yang aktif dalam menentukan dirinya, sehingga apa yang dilakukan lebih banyak berasal dari dalam dirinya. Istilah self regulation digunakan oleh aliran teori sosial kognitif sebagai bagian internal yang mengatur dan menguasai diri manusia, sedangkan faktor eksternal hanya menguatkan faktor internal yang telah ada pada diri seorang manusia. ${ }^{15}$ Faktor eksternal ini erat kaitannya dengan kerangka sosial budaya (sociocultural framework) kader dan masyarakat yang bersangkutan. Kerangka sosial budaya adalah suatu kerangka berpikir menurut cara pandang terintegrasi yang bergerak dan dapat dibagi menurut rincian dalam berbagai peringkat, seperti peringkat ideologi, institusi, dan organisasi yang tidak terlepas dari sejarah perkembangan masyarakat itu. Masyarakat Sunda memandang penting dirinya dan orang lain, karena itu lingkungan sosial menjadi perhatian bagi setiap orang dengan tetap memperhitungkan dirinya dalam peranan tersebut. ${ }^{12}$ Hal ini berbeda dengan teori Herzberg yang menyatakan bahwa faktor motivasi eksternal (hygiene factor) tidak akan mendorong minat orang untuk bekerja lebih baik, akan tetapi jika faktor ini dianggap tidak dapat memuaskan dalam berbagai hal seperti insentif yang tidak memadai dan lingkungan yang tidak menyenangkan, maka faktor-faktor itu dapat menjadi sumber ketidakpuasan yang potensial untuk menurunkan motivasi. ${ }^{14}$

Motif menjalin hubungan dengan masyarakat merupakan hal biasa yang mereka lakukan dan secara spontan mempengaruhi jawaban mereka sehingga motivasi eksternal lebih mendominasi dibandingkan dengan motivasi internal dalam keterlibatan kader aktif pada pelaksanaan kegiatan posyandu. Perilaku kedekatan dengan sesama seperti bertetangga, bergaul akrab, membuat keterikatan yang kuat merupakan sifat dasar yang melekat pada masyarakat Indonesia, khususnya masyarakat Sunda. Keakraban dan kekerabatan yang kental mempunyai dampak lebih jauh dengan skala lebih besar, yaitu mudah terciptanya kerja gotong royong di antara mereka. Budaya kerja gotong royong ini masih sangat dominan berlaku di daerah pedesaan. ${ }^{16}$ Penelitian ini dilakukan pada kader dan masyarakat di kabupaten Kuningan yang sebagian besar suku Sunda dengan salah satu karakter budaya "silih asah, silih asih, dan silih asuh" (saling mengasihi, saling mempertajam diri, dan saling memelihara serta melindungi) dan mengenal peribahasa turun temurun dan melekat pada tingkah laku seharihari yaitu 'ulah ngukur baju sasereg awak'; artinya jangan melihat sesuatu itu hanya dari kepentingan pribadi yang semuanya ini mempengaruhi berbagai aspek kehidupan, khususnya aspek hubungan sosial sebagai kontributor terbesar terbentuknya motivasi peran sertanya kader dan masyarakat dalam kegiatan posyandu.

Seringnya kader aktif berinteraksi dengan pihak lain misalnya dinas kesehatan ataupun kecamatan dalam bentuk pembinaan, penyuluhan, dll. menjadikan kader aktif merasa nyaman dengan lingkungannya. Motivasi dari lingkungan atau iklim organisasi dapat membangkitkan motivasi sesuai pendapat Litwin dan Stringer yang dikutip Moekijat ${ }^{17}$ yang menyatakan bahwa terdapat hubungan antara iklim/lingkungan dan motivasi.

Kenyataan ini berbeda dengan model kelompok kader tidak aktif yang memperlihatkan 
faktor motivasi internal memiliki nilai lebih bermakna. Hal ini sesuai dengan teori motivasi Herzberg yang menyatakan bahwa motivasi internal merupakan faktor pendorong semangat guna mencapai hasil yang lebih baik. Pemuasan terhadap kebutuhan tingkat tinggi (motivation factor) lebih memungkinkan seseorang untuk berbuat lebih baik dibandingkan dengan pemuasan kebutuhan lebih rendah (hygienis), ${ }^{14}$ artinya bahwa dalam diri kader tidak aktif sebenarnya motivasi untuk terlibat dalam kegiatan posyandu sangat besar, tetapi masih memiliki hambatan lain yang menyebabkan mereka tidak dapat optimal untuk terlibat. Hal ini terlihat dari karakteristik responden yang menunjukkan persentase terbesar kader tidak aktif adalah pekerja seperti menjadi pegawai negeri atau swasta sehingga tidak mungkin terlibat lebih jauh dalam pelaksanaan kegiatan posyandu karena kesibukan pekerjaan.

Simpulan, pengaruh dan perbedaan pengaruh motivasi pada peran serta kader dan masyarakat menentukan keberhasilan kegiatan posyandu.

\section{Daftar Pustaka}

1. Departemen Kesehatan RI. Informasi ringkas paradigma sehat. Jakarta: Pusat Promosi Kesehatan; 2002.

2. Dinas Kesehatan Provinsi Jawa Barat. Profil Kesehatan Provinsi Jawa Barat tahun 2005. Bandung: Dinkes Jabar; 2006.

3. Muninjaya AA. Manajemen kesehatan. Jakarta: Penerbit Buku Kedokteran EGC; 2004.

4. Uci Sanusi. Beberapa faktor yang berhubungan dengan keaktifan kader Posyandu di wilayah UPTD puskesmas pasawahan kabupaten Kuningan Tahun 2006 [tesis]. Tasikmalaya:
Fakultas Kesehatan Masyarakat Universitas Siliwangi; 2006.

5. Dinas Kesehatan Kabupaten Kuningan. Rencana kegiatan peningkatan program posyandu tahun 2008. Kuningan: Dinkes kabupaten Kuningan; 2007.

6. Wiku Adisasmito. Sistem kesehatan. Jakarta: PT. Rajagrafindo Persada; 2007.

7. Singarimbun M, Effendi S. Metode penelitian survai. Cetakan kedua. Jakarta: PT Pustaka LP3ES Indonesia; 1995.

8. Jöreskog KG, Sörbom D. LISREL 8: structural equation modeling with the SIMPLIS command language. London: Lawrence Erlbaum Associates Publisher; 1993.

9. Robbin SP. Organizational behaviour: concept, controvercies, aplications. Edisi ke-8. New York: Prentice Hall Inc; 2003.

10. Yusi Ratna Suminar. Analisis pengaruh pengetahuan, supervisi dan motivasi terhadap kinerja petugas tuberkulosis paru Puskesmas di Kabupaten Sumedang tahun 2006 [tesis]. Bandung: Program Pascasarjana Universitas Padjadjaran; 2006.

11. Ivancevich JM, Donnelly JH, Gibson JL. Management principles and functions. Edisi ke-4. India:A.I.T.B.S Publihser \& Distributors; 2005.

12. Garna JK. Budaya Sunda; melintas waktu menantang masa depan. Bandung: Lembaga Penelitian Unpad; 2008.

13. Suryana LI, Sumantri S. Psikologi personel. Bandung: Universitas Padjadjaran; 2005.

14. Feldman RS. Elements of psychology. United States of America: McGraw-Hill, Inc.; 1992.

15. Winardi J. Motivasi \& pemotivasian dalam manajemen. Jakarta: Rajawali Pers; 2001.

16. Koentjaraningrat. Manusia dan kebudayaan di Indonesia. Edisi ke-18. Jakarta: Penerbit Djambatan; 1999.

17. Moekijat. Dasar-dasar motivasi. Bandung: PT. Pionir Jaya; 2002. 